\title{
o uso de fontes em sala de aula: a obra de Maria Firmina dos Reis (1859) como mediadora no estudo da escravidão negra no Brasil
}

\author{
The use of sources in classroom: the work of Maria \\ Firmina dos Reis (1859) as a mediator in the study of \\ black slavery in Brazil
}

Janaína Santos Correia

RESUMO

Partindo do pressuposto de que a escola também produz conhecimento histórico, discute-se a importância do uso de fontes em sala de aula, uma das premissas para a construção da literacia histórica, apresentando como proposta de trabalho o uso do romance "Úrsula" de Maria Firmina dos Reis (1859), como uma rica fonte histórica ao apresentar uma visão de escravo como sujeito histórico. Maria Firmina dos Reis aventurou-se a escrever dentro das possibilidades que a sociedade brasileira do século XIX impunha à época, driblou as agruras de seu tem po e em 1859 publica seu romance "Úrsula", obra singular por ser composta por uma mulher de descendência africana na qual se evidencia a condição de desigualdade a que as mulheres, africanos e seus descendentes estavam submetidos no Brasil oitocentista, em decorrência do regime patriarcal. Considera-se o conhecimento prévio sobre o tema, apresentado por alunos de Ensino Médio oriundos de dois colégios públicos localizados em Londrina (PR), visto que o novo conhecimento se origina a partir de conhecimentos anteriores, apontando, entre outros, a importância das telenovelas, dos materiais didáticos nas representações encontradas. Apresenta-se uma discussão do debate nacional sobre escravidão negra no Brasil onde o escravo passa a ser visto como um sujeito histórico, a partir de novas abordagens balizadas em fontes e pesquisas documentais renovadas evidenciando a relativa autonomia de africanos e seus descendentes em cativeiro e os avanços na luta por uma história afro-brasileira, através da lei 10.639/03 que tornou obrigatório no currículo escolar da educação básica o estudo da História da África. Discute-se emprego de fontes históricas em sala de aula de forma crítica, contribuindo no processo de ensino e aprendizagem que tem como pressuposto a pesquisa, o debate, a formação do espírito crítico e inventivo, introduzindo os alunos no 


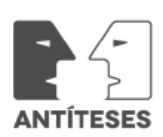

fazer historiográfico e/ou na construção do conhecimento histórico. Inferem-se os resultados positivos ao utilizar a obra de Firmina na construção de uma visão do escravo como agente histórico, permeando o estudo da escravidão negra no Brasil, por direções mais gerais tornando o aprendizado mais produtivo e desafiador. Em suma infere-se que a história e a literatura, no processo de ensino, possibilitam espaço privilegiado de produção do conhecimento histórico escolar.

Palavras-chave: Ensino de História. Literatura. Escravidão. Literacia histórica.

\section{ABSTRACT}

Assuming that school also produces historical knowledge, the importance of using sources in classroom is discussed as one of the premises for the construction of historical literacy, presenting as work proposal, the use of the novel "Ursula", written by Maria Firmina Reis (1859), as a rich historical source by presenting a vision of the slaves as historical subjects. Maria Firmina dos Reis ventured to write within the possibilities that Brazilian society of the nineteenth century imposed at the time, dribbling the difficulties of her time and, in 1859, publishing her novel "Ursula", an unique work made by a woman of African ancestry in which is highlighted the condition of inequality that women, African and their descendants were submitted in nineteenth-century Brazil, due to the patriarchal system. It is considered the prior knowledge on the topic that is presented by high school students from two public schools located in Londrina (PR), whereas the new knowledge arises from prior knowledge, pointing, among others, the importance of soap operas and representations found in textbooks. It is presented a discussion on the national debate about black slavery in Brazil where the slave is seen as historical subject, from new approaches buoyed in sources and renewed documentary research showing the relative autonomy of African and their descendants in captivity and advances in the fight for a African-Brazilian history, through the law 10.639/03, which made compulsory in the curriculum of basic education the study of African history. It is also approached the work with historical sources in a critical way in classes, contributing to the process of teaching and learning whose basis consists in research, discussion, formation of critical and inventive minds, introducing students to the historiographical process and/or construction of historical knowledge. Positive results are inferred by the use of Firmina's work in building a vision of the slave as historical agent, permeating the study of black slavery in Brazil with more general directions, making the learning process more productive and challenging. In short, it appears that history and literature, in the teaching process, enable a privileged space for the production of historical knowledge at school.

Keyword: History Teaching. Literature. Slavery. Historical Literacy. 